\begin{tabular}{|c|c|c|}
\hline \multirow{2}{*}{\multicolumn{2}{|c|}{$\begin{array}{l}\text { DE } \\
\text { DE GRUYTER } \\
\text { OPEN }\end{array}$}} & ECONOMIC THEMES (2017) 55(1): 39-53 \\
\hline & & DOI 10.1515/ethemes-2017-0003 \\
\hline
\end{tabular}

\title{
THE ROLE OF DEPOSIT FINANCIAL INSTITUTIONS IN THE DEVELOPMENT OF REAL SECTOR IN THE REPUBLIC OF SRPSKA
}

\author{
Vitomir Starčević \\ University of East Sarajevo, Faculty of Business Economics Bijeljina, \\ Republic of Srpska, Bosnia and Herzegovina \\ $\triangle$ vitomir.starcevic@fpe.unssa.rs.ba
}

\section{Slobodan Subotić}

University of East Sarajevo, Faculty of Transport and Traffic Engineering Doboj,Republic of Srpska, Bosnia and Herzegovina

$\bowtie$ subotics@telrad.net

\section{Irena Đalić}

University of East Sarajevo, Faculty of Transport and Traffic Engineering Doboj,Republic of Srpska, Bosnia and Herzegovina

$\bowtie$ i.naric@yahoo.com

UDC

336.1.07(49

7.1)

Review

paper
Received: 12.07.2016. Accepted: 02.03.2017.

\begin{abstract}
Deposit financial institutions are known for a wide range of providing traditional financial services, from current accounts and systems of planning of savings, to granting loans to companies, clients and countries. At the present time, deposit financial institutions do not limit their services only to those traditional, but quickly begin providing general financial services, such as: securities trading, protection insurance, financial planning, management of pension systems, the provision of advisory services to companies that are in the process of fusion, and other new services. The objective of the paper is to present the deposit financial institutions which operate in the Republic of Srpska and determine their role in the development of the real sector. Research work should show whether the deposit financial institutions, such as financing sources, are the development drivers of the real sector in the Republic of Srpska or limiting factor in the development of this sector.
\end{abstract}

Keywords: deposit financial institutions, financial services, loans, real sector.

JEL classification: G2, G21 


\section{Introduction}

Deposit financial institutions and their financial competitors offer a wide range of similar financial services, which are expanding and evolving rapidly. The spectrum of services and how modern financial institution provide those services, in practical terms much facilitate daily operations of users of services, than they can satisfy almost all their financial needs in one financial institution, and on one place. Banks and some of their competitors have become truly financial department stores of the modern age, with the aim to combine banking, fiduciary and insurance services as well as brokerage services.

The structure of financial intermediaries and types of financial institutions are considerably different from one economy to another. In developed economies, the structure of institutions is very rich, and there are different types of institutions which, according to their financial resources, are very powerful. In contrast to developed economies that have complex financial systems, and therefore institutions, in developing countries and countries in transition, financial systems are very simplified with poorly developed financial market, with a modest structure and limited types of financial institutions (Plakalović, N., 2004, p. 64).

For the purpose of testing the starting hypotheses, quantitative methodology was applied in the paper. The paper has two structural parts. The first part provides an overview of theoretical and empirical considerations of the effects of FDI inflow and measuring of company's performance. The second part elaborates the results of the conducted research.

\section{The Importance of Financial Services}

The processes of globalisation that have engulfed the world economy caused significant changes in the bank industry. Banks more and more look like financial supermarkets which offer a complete service from the classic work through investment banking, insurance and trade securities. The requirements of modern banking have caused that most of the tasks that have been exclusively in the domain of banks have become the subject of action of various financial institutions. In addition, new jobs and new technological solutions conditional on banks and other financial institutions provide financial services, while constantly adapting. In fact, they have found new models and instruments, and significant part of the business they have transferred to the broadcasters. Banks are only one part of a large financial market system whose main purpose is to encourage individuals and institutions to savings. That savings, banks and other financial institutions continue to convey to those individuals and institutions that are planning to invest in new projects, products and services. 
System of financial markets and institutions has a much more important role than the role of converting savings into investment. The system also offers various ancillary services that are essential for the modern way of life. These are payment services that make possible trade and market (based on checks, credit cards and websites that are used for these purposes) and risk protection of those who are saving and planning to invest (including insurance policies and transactions with derivative instruments). Then, access to liquid funds (convert the assets and holdings in immediately available funds) and granting loans to those who need loans to supplement incomes and increasing living standards (Rose \& Hudgins, 2005, p. 8).

For centuries, banks dominated over other financial institutions in the provision of financial services. However, today, the situation has greatly changed, and the share of banks in the financial market has significantly decreased (reduced) by the emergence of other financial institutions. Today, banks and most of their competitors are very complex financial organisations. They offer various financial services through a large number of departments and agencies in which they employ experts from various financial authorities. The management of every modern financial institutions make decisions about: (a) which customers the loan will be approved, (b) what securities should be entered, or should not enter in the portfolio of financial institutions, (c) what conditions should be offered to customers when we talk about loans, deposits, investments and other services, and (d) what sources of capital institution primarily should rely on.

Banks and their finance competitors offer a wide range of similar financial services that are rapidly expanding and evolving (Internet services, smart cards, etc.). "This is an impressive range of services, and the manner by which modern financial institutions provide these services, in practical meaning they very facilitate everyday tasks to their customers so that they can satisfy almost all their financial needs in one financial institution, and in one place. Banks and some of its competitors have become truly financial department stores of the modern era, with the aim to consolidate the banking, fiduciary and insurance services, as well as brokerage services in securities, under one roof” (Rose \& Hudgins, 2005, p. 20).

Financial services occupy an important place in the economy of each country, and because of that, it is very important to have regulated and stable financial system. Only the establishment and maintenance of security and stability in all segments of the financial system can maintain public confidence in the work of financial institutions which, in the financial system, are conducted by two groups of activities.

The first group of activities performed by financial institutions is transmission in the process of indirect funding. Financial institutions sell financial instruments to the surplus sector, collect the money and capital and invest it in the financial instruments of deficient sector. In this way, they become financial intermediaries, 
because they collected funds by emitting financial liabilities, followed, the collected funds in this way, they invested in financial assets. These activities are performed by: commercial banks, savings banks, finance companies, investment funds, insurance companies and pension funds.

The second group of activities relates to the services in the process of direct financing. In this case, the financial institution does not broadcast its financial instruments but provides financial services and provides conditions for carrying out the direct supply of financial instruments between surplus and deficient sector. "In other words, these institutions enable the mass, regulated and standardized operation of direct financing in the financial market. This group of activities is performed by: brokerage and dealer houses, investment banks, investment advisers and organised markets (stock exchanges and OTC markets)" (Šoškić \& Živković, 2006, p. 16).

Financial institutions carry out their activities in the process of connecting surplus and deficient sectors. They can be divided in several ways and in several groups. According to (Vunjak \& Kovačević, 2006, p. 15) financial institutions can be classified as:

1) Bank (deposit) financial institutions,

2) Non-bank financial institutions,

3) Institutional investors and intermediary institutions.

The complex interdependence of supply and demand of funds, financial intermediaries and financial markets is presented in Figure 1. Population, companies and states as participants in the financial market are on the side of supply and demand of funds. If they have free funds, they bring them through financial institutions, or through direct participation in the financial markets, placing them to those who need these funds for investment. In the absence of funds, they acquire the same through financial institutions, or directly in the financial markets.

On the other hand, in the financial markets there are financial institutions that perform the function of collecting funds and directing them into financial investments. In fact, they are intermediaries in the transfer of funds between those who have a surplus of funds and those who need these funds. The owners of the funds who have financial savings in the current period, the same shall make available to financial institutions and they are included in the transfer of funds, or carry out of their investments. 
Figure 1. The interdependence of supply and demand of funds,financial intermediaries and financial market

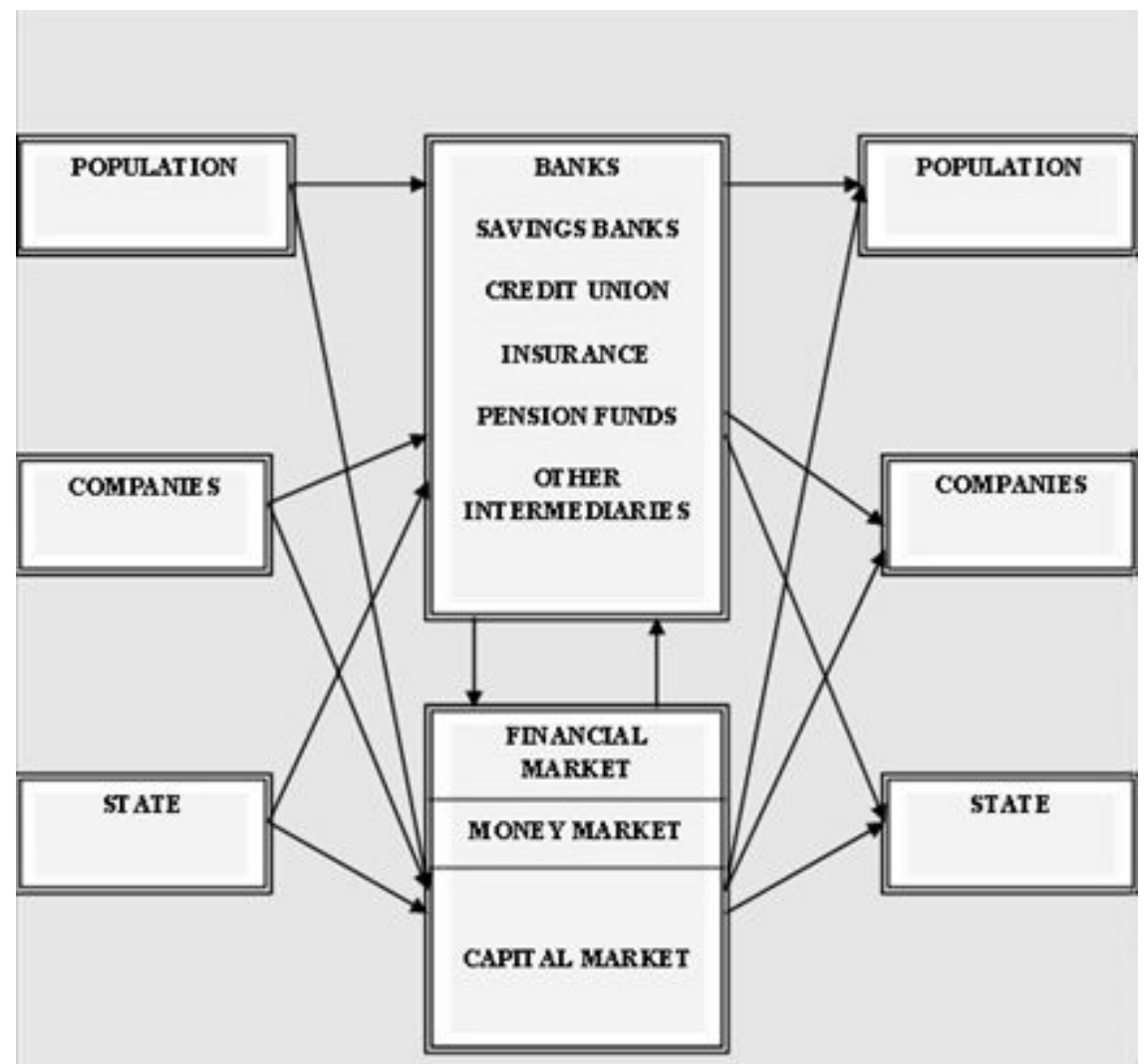

Source: Lorens J.G., Principles of Managerial Finance, Harper and Row, Publishers, Inc., New York, 1976., p. 450

\section{Structure of Deposit Financial Institutions in the Republic of Srpska}

Bank system of the Republic of Srpska consists of banks, microcredit organisations, savings and credit organisations and other financial organisations whose establishment and operations are regulated by special laws, which stipulate that the Banking Agency of the Republic of Srpska issues permits or approvals, supervises operations and does other activities in association with them. The bank sector in Republic of Srpska is the most important part of the entire bank system of Republic of Srpska and consists of nine deposit or commercial banks. The bank sector serves as interbank payment system and plays a significant role in preventing of money laundering. 
Deposit (commercial) banks in the Republic of Srpska are mostly private. According to the ownership structure of the share capital at the date of Dec $31^{\text {st }}$ 2015, private capital makes $94 \%$ and state capital makes $6 \%$ of the share capital.

Figure 2. The ownership structure of deposit (commercial) banks in Republic of Srpska

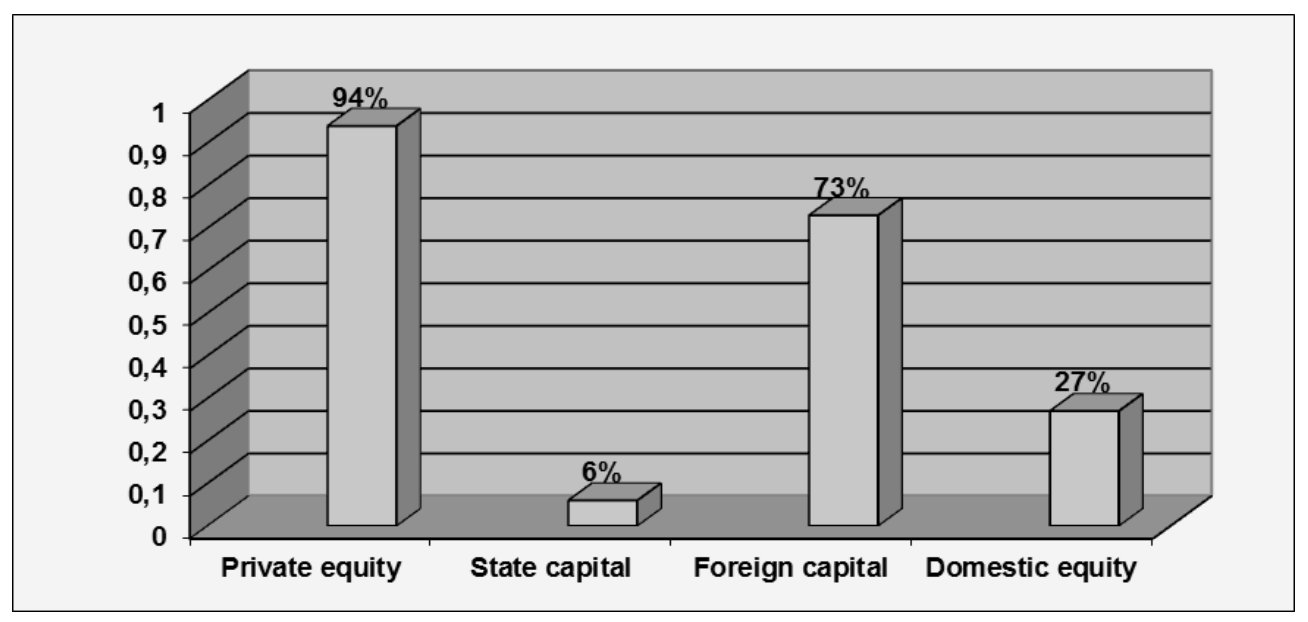

Source: (ABRS, Report for 2015)

The ownership structure of the capital of deposit banks at the date of December $31^{\text {st }}$ 2015, shown in the Figure 1, shows that there is a dominant participation of foreign private capital. The leading role in the ownership structure still holds Austria with a share of $46.71 \%$ with a majority of capital in three banks. Per one bank is majorly owned by shareholders from Slovenia, Serbia and the United States (three banks). Three banks are majorly owned by domestic shareholders (one bank is state-owned). Domestic shareholders participate with $27.08 \%$ of the total share capital of the bank sector in Republic of Srpska, while foreign shareholders participate with $72.92 \%$ of the total share capital of the bank sector in the Republic of Srpska.

Activities in banks were conducted in terms of the slow recovery of economic activity and difficulty of operate in the real sector, which is reflected on the state and prospects of the bank sector, and because of this, there is increased exposure to credit risk as the most important risk, and liquidity risk management has gained importance.

In addition to commercial banks, Investment-Development Bank (IDB RS) which was founded in 2006 with headquarters in Banja Luka operates in the banking sector of the Republic of Srpska. The strategic objectives of the Bank are encouraging investments and stimulating development in the Republic of Srpska. Strategic objectives and priorities of the IDB RS are: (1) Improvement of agricultural production (2) Support to SMEs, (3) Residential and commercial 
construction, (4) Construction of infrastructure in the RS (5) Increase of employment, (6) Support to production to reduce the trade deficit, (7) Equal regional development, (8) Improving corporate management and capital markets, (9) The efficient process of implementation of the privatization and restructuring of companies in the context of the privatization (10) Support to investments (11) Environmental protection. (Source: www.irbrs.net). The role of the IDB RS is a professional and efficient management of the assets of the Republic of Serbian, which is formally and legally registered in six funds. The Bank does not perform direct placements of funds intended for development projects, than through 7 commercial banks and three micro credit organisations. For specific projects IDB has support from international financial institutions (World Bank, European Investment Bank and the European Bank for Reconstruction and Development, etc.).

Investment-Development Bank of the Republic of Srpska is institutionally organised as a joint stock company owned by the Republic of Srpska. It consists of six funds, which are also organised as joint stock companies. These funds are: (1) Housing Fund, (2) The Fund for Development and Employment, (3) Development Fund of the eastern part of RS, (4) Share Fund RS, (5) The Fund for the registration of RS and (6) Fund management of real estate and claims in property of RS.

Activities of Investment-Development Bank of the Republic of Srpska are primarily focused on the funding of those projects that are vital for the national economy. However, the bank in accordance with the set of strategic goals and priorities provides adequate financial support to small and medium-sized enterprises in the Republic of Srpska. The Government of the Republic of Srpska establishes the criteria for lending to small and medium-sized enterprises and entrepreneurs, which are stimulating, while interest rates are lower than those that small businesses and entrepreneurs are paying to commercial banks. An exceptional advantage of all loans are longer repayment periods, which commercial banks, currently, can not to offer (http://www.vladars.net/sr-SPCyrl/Vlada/Ministarstva/mf/Pages/default.aspx, 2017).

\section{Deposit Financial Institutions in the Function of Financing of the Real Sector in Republic of Srpska}

Companies in Republic of Srpska are increasingly faced with the problem that the need for funds exceeds the volume of newly created cash accumulation that remains available to them. These trends direct financial demand of enterprises to banks and bank loans. Approving and disbursing loans, banks allow to companies to maintain current liquidity, permanent continuity and stability of operations.

Increase and presence of foreign banks in the territory of Bosnia and Herzegovina and in neighbour countries, and the establishment of the Deposit 
Insurance Agency in Bosnia and Herzegovina, has influenced the growth of confidence in the banking sector, which resulted in the growth of savings and in reduction in interest rates and commissions, and in the quality of banking services. Albeit the banking sector is quite developed, and commercial banks play a key role in lending to enterprises and entrepreneurship, they are still in a very unfavourable position of getting the loan. The commercial (depository) banks grant loans to small and medium enterprises and entrepreneurs under adverse conditions and terms of repayment. Banks granted short-term and long-term expensive loans justifying this with high-risk business in such conditions that prevail in the economy of the Republic of Srpska and in the Federation of B\&H. Therefore, banks are emphasizing the need to improve the legal protection in the field of debt collection and financial discipline.

According to the analysis of the European Commission, Bosnia and Herzegovina (composed of two entities: Republic of Srpska and the Federation of $\mathrm{B} \& \mathrm{H}$ ), of all the Balkan countries, was the country with the worst conditions for financial support to SMEs. With regard to Croatia and Serbia in Bosnia and Herzegovina there are double worse conditions and unfavourable loans. However, they show very different situations in different countries (https://ec.europa.eu/commission/index_sl, 2017). In contrast, in Albania, the demand for bank loans is very low. In some countries, including Bosnia and Herzegovina, in addition to competitive bank sector and lowering of cost of credit, lack of financial condition limits their expansion.

The same research shows that, contrary to the Western Balkan countries, in developed market economies, the financing of enterprises from internal resources is significantly lower and amounts to $63 \%$. Financing through bank loans by $13.8 \%$ was slightly lower than in the countries of the Western Balkans. However, in these countries we have expressed great share of the share capital (11.1\%), leasing arrangements (5.3\%) and commercial loans (2.3\%). It should be noted that the intensity of enterprise funding from internal sources is the least pronounced in Turkey by $55.7 \%$, while the share of the share capital is very high and amounts to $30.6 \%$. Financing through leasing is minimal, amounting to only $0.7 \%$. This points to the fact that the companies in this country are very extent in the capital market (Source: European Commission, www.europa.eu.int/coom/).

The bank sector in the Republic of Srpska in 2015 was consisted of 9 banks, of which 8 banks was with majority private capital, with the dominance of foreign private capital, while the one bank remains as state-owned.

The ownership structure is characterised by majority private ownership in eight banks, with a dominant share of foreign private capital, and the state capital in the one bank. One bank with majority private capital has a significant share of the state capital by $19 \%$ percent. 
The share capital in the bank sector in the Republic of Srpska on the date 12.31.2015 amounted to 629.1 million BAM and compared to the end of 2014 it increased by 44.1 million BAM or $8 \%$ for capital increase (four banks), with a slight change in the ownership structure. Thus, the share of private capital amounted to $94 \%$ (and at the end of 2014 was amounted to 93\%) and the state capital amounted to 6\% (and at the end of 2014 was amounted to 7\%). It should be noted that the share capital of the cooperative does not affect to the ownership structure. The structure of the share capital by origin country as at 12.31 .2015 , in relation to 12.31 .2014 , was changed by the increase in the share of domestic (private) capital by 4.73 percentage points and fall of foreign capital in the same proportion. (Source: ABRS, https://www.abrs.ba/, 2015).

The total volume of business in the bank sector of the Republic of Srpska at the end of 2015 was about at the same level as at the end of 2014. This period was characterised by significant investments in trade of securities with a nominal increase of 57.8 million BAM or 15\% and with a growth by $2 \%$ in gross loans or 113.9 million BAM. The growth of the aforementioned activities of the bank sector is mainly funded by deposits, and they were higher by 193.5 million BAM or $4 \%$, while liabilities of the bank sector was significantly reduced by 171.7 million BAM or $22 \%$, as well as funds which recorded a decrease by 83.7 million or $6 \%$, all compared to the end of 2014 (Source: ABRS, 2015).

The negative impact of the global economic and financial instability, as well as the harmful effects caused by the floods of 2014, continues to indirectly reflect to the deterioration of qualitative indicators of business in the bank sector through the real sector where the consequences are greatest and through the citizens sector. Therefore, it was expected that, in the future, these events will have indirectly affect to the indicators of the business in the bank sector through difficulties in collection of credit receivables.

Activities of the bank sector in Republic of Srpska can be seen through the structure of the balance of commercial (depository) banks. From the structure of liabilities, it can be concluded that the deposits are the main source of funds of commercial banks. Deposits of commercial banks in the Republic of Srpska participate with $75 \%$ of total liabilities and on December $31^{\text {st }} 2015$, it amounted to $4,956.5$ million BAM, with a growth rate of $4 \%$ compared to the same period in 2014.

Obligations based on loans are decreased by 171.7 million or 22\%, but they are still significant item in the structure of liabilities, in the amount of 625.7 million, accounting by $9 \%$ of total liabilities (decline in the share by 3 percentage points compared to the end of 2014). The structure of borrowings consists of: loans from the Investment Development Bank of the Republic of Srpska (IDB RS) in the amount of 502.9 million and a share of $80.4 \%$ in total liabilities based on loans, and rate of decrease by 12.9\% compared to the end of 2014 (577.3 million), loans from 
foreign banks and international financial institutions in the amount of 114.3 million KM or $18.2 \%$ of total liabilities based on loans with a rate of decline by $44.9 \%$ (in the end of 2014 they were amounted 207.4 million) and loans from other sources (public institutions and other domestic sources) in the amount of 8.5 million or $1.4 \%$ of total liabilities based on loans (in the end of 2014 they were amounted 12,7 million). (Source: ABRS, 2015).

The credit function is one of the basic functions of activities of deposit banks, which is proved by the participation of net loans by $65 \%$ in total assets. Therefore, the level of total loans is the most important indicator of the volume of activities of each bank and of the whole sector, but also it is the largest potential generator of risk in the business. Gross loans of deposit banks in 2015 amounted to 4,774.06 million BAM.

Table 1. Overview of loans extended by banks by sectors

\begin{tabular}{|r|l|r|r|r|r|}
\hline \hline No. & Description & Dec, 2012. & Dec, 2013. & Dec, 2014. & Dec, 2015. \\
\hline 1. & Government and Government Institutions & 600.542 & 675.378 & 765.563 & 702.673 \\
\hline 2. & Public and state enterprises & 178.476 & 211.472 & 218.372 & 213.570 \\
\hline 3. & Private enterprises and societies & $\mathbf{2 . 0 3 9 . 8 3 7}$ & $\mathbf{2 . 1 0 3 . 2 1 6}$ & $\mathbf{1 . 7 9 3 . 7 8 9}$ & $\mathbf{1 . 8 2 7 . 4 1 0}$ \\
\hline 4. & Non-profit organizations & 10.109 & 14.470 & 11.401 & 10.716 \\
\hline 5. & Banks and bank institutions & 0 & 0 & 0 & 0 \\
\hline 6. & Non-banking financial institutions & 17.616 & 16.096 & 16.849 & 14.746 \\
\hline 7. & Citizens & 1.680 .866 & 1.805 .405 & 1.914 .817 & 1.997 .259 \\
\hline 8. & Other & 19.518 & 49.585 & 12.097 & 7.692 \\
\hline & IN TOTAL: & $\mathbf{4 . 5 4 6 . 9 6 4}$ & $\mathbf{4 . 8 7 5 . 6 2 2}$ & $\mathbf{4 , 7 3 2 . 8 8 8}$ & $\mathbf{4 , 7 7 4 . 0 6 6}$ \\
\hline \hline
\end{tabular}

Source: ABRS, Annual Reports

Loans granted to the real sector by deposit banks have a fluctuating trend. After period of recession caused by great financial crisis, whose consequences we can still feel today, there is increased lending in the real sector of economy of Republic of Srpska. This increase is particularly pronounced in the first two years of the observed period (Table 1), when the banks invested 2039.8 million KM of loan to the private companies in 2012, which was higher by 5.79\% compared to 2011 $(1,928,04$ million KM). Loans placed to this sector in the next 2013.show a tendency of growth by $3.10 \%$. However, a sudden drop in lending to private companies coming in 2014 by $14.71 \%$, with a slight increase by $1.87 \%$ in 2015 . Trend of loans to the public and state enterprises had not large fluctuations, moving somewhat evenly across all years of the period, what is shown in the Figure 3. 
Figure 3. Trend of lending to enterprises in the Republic of Srpska

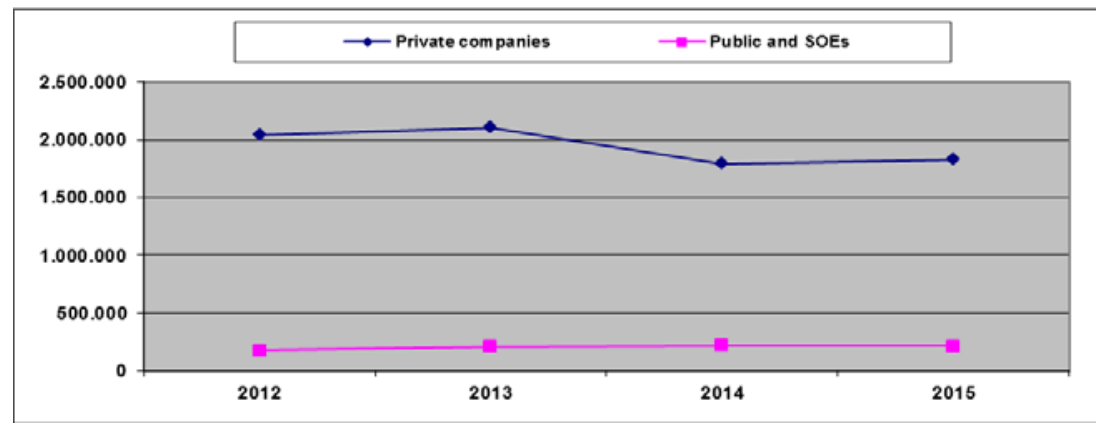

Source: Data from Table 1.

Research of the business environment in the countries of the Western Balkans, which were conducted by the European Bank for Reconstruction and Development, demonstrating the difficulty for companies that are trying to get a bank loan. For almost half of the private companies surveyed in the Western Balkans, including Bosnia and Herzegovina, the inability to access to the bank financing is a major problem in the business. The time what it takes to approve the loan and the collateral that banks require are the other problems that have been identified.

In Bosnia and Herzegovina and in Republic of Srpska, the deposit banks require high security of loans and thereby they are shifting a greater risk to enterprises. As a guarantee usually are used: deposits, guarantees of other commercial banks, real estate, promissory notes of debtors and other forms of securing of credit. An additional problem for companies who are applying for this type of loan is also extensive amount of documents. The amount of loan mainly depends on the credit standing of the company.

Nominal interest rate by which banks in the Republic of Srpska grant loans to private sector is still high. Loan processing fee ranges from $0.5 \%$ to $2 \%$ on the amount of approved loan, what has influence on the amount of effective interest rate. So, commercial banks grant expensive short-term and long-term loans to enterprises, with unfavourable repayment period, what they justify with a high risk of business. Certainly, this is one of the reasons that credit investments in Republic of Srpska have shown the tendency to fall in the last two business years. This suggests that private companies are directed to other funding sources that replace the classic bank loans.

Total average weighted nominal and effective interest rates on bank loans in Republic of Srpska, in the period of January-December 2015, decreased in comparison to the same period of 2014, so that, at the date of 12.31.2015, the average nominal interest rate decreased by 0.39 percentage points, and the average effective interest rate decreased by 0.45 percentage points compared to the average of the same in 2014. However, despite the reduction in comparison to 2014, 
interest rates of deposit banks which placed short-term and long-term loans to the economy are still high and inaccessible. This particularly applies to long-term loans with an average weighted effective interest rate which is significantly higher compared to loans placed to the government and government institutions.

Table 2. The average weighted interest rate in the Republic of Srpska

\begin{tabular}{|c|c|c|c|c|}
\hline \multirow{4}{*}{ D E S C R I P T I O N } & \multicolumn{4}{|c|}{ The average weighted interest rate } \\
\hline & \multirow{2}{*}{\multicolumn{2}{|c|}{$\begin{array}{c}\text { I-XII } \\
\text { Banks } \\
\text { RS } \\
\end{array}$}} & \multirow{2}{*}{\multicolumn{2}{|c|}{$\begin{array}{c}\text { I-XII } 2015 . \\
\text { Banks } \\
\text { RS }\end{array}$}} \\
\hline & & & & \\
\hline & NIR* & EIR** & NIR & EIR \\
\hline 1. Average weighted interest rates on short-term loans & 6,22 & 7,22 & 5,71 & 6,29 \\
\hline 1.1. Loans to government and government institutions & 4,75 & 4,88 & 5,07 & 5,15 \\
\hline 1.2. To economy & 6,91 & 8,22 & 5,80 & 6,41 \\
\hline 1.3. Loans to banks and other fin. institutions & 6,77 & 7,56 & 8,07 & 10,48 \\
\hline 1.4. To population & 9,79 & 13,74 & 9,08 & 13,01 \\
\hline 1.5. Other loans & 8,86 & 14,97 & 7,24 & 7,90 \\
\hline 2. Average weighted interest rates on long-term loans & 7,26 & 8,26 & 7,14 & 8,47 \\
\hline 2.1. Loans to government and government & 5,83 & 6,25 & 6,12 & 6,42 \\
\hline 2.2. To economy & 7,11 & 7,72 & 6,79 & 7,49 \\
\hline 2.3. Loans to banks and other fin. institutions & 3,06 & 3,16 & 3,00 & 3,02 \\
\hline 2.4. To population & 7,72 & 9,18 & 7,46 & 9,32 \\
\hline 2.4.1. Mortgage loans & 5,47 & 6,21 & 5,11 & 5,68 \\
\hline 2.5. Other loans & 8,50 & 9,08 & 6,35 & 6,78 \\
\hline 3. Total weighted interest rate & 6,77 & 7,77 & 6,38 & 7,32 \\
\hline
\end{tabular}

*NIR- Nominal interest rates, **EIR- The effective interest rates

Source: ABRS, Annual Reports

According to data of ABRS for 2015, the total weighted average effective interest rate on loans, in the reporting period, decreased by 0.67 percentage points in the units of banks from the Federation of B\&H, which operate in the Republic of Srpska. The units of banks from the Federation of $\mathrm{B} \& \mathrm{H}$, which operate in the Republic of Srpska, have a higher weighted average effective interest rate by 1.1 percentage point on the same loans than banks in the Republic of Srpska.

The units of banks from the Federation of B\&H, in 2015, had slightly less weighted average effective interest rate on loans based on overdrafts (legal entities and population) than the banks in the Republic of Srpska (effective interest rate 
decreased by 0.55 percentage points), while for population overdrafts it was decreased by 0.75 percentage points. However, banks in the Republic of Srpska have significantly higher weighted average effective interest rate on demand deposits (legal entities and population) than the same interest rates in banks from the Federation of B\&H (by 0.17 percentage points).

\section{Conclusion}

Developed financial institutions and unhindered access to sources of financing are of the great importance for the development of the real sector of each country. It is well known fact that the structure, sorts and different types of financial institutions in developed market economies are different than those in transition countries. In contrast to the developed economies, with complex financial systems and developed financial institutions, the financial system of Republic of Srpska is characterised by underdeveloped financial markets with a limited number and types of financial institutions, where deposit (commercial) banks are dominant. They represent a significant source of financing for private companies and they mostly direct its credit placements, although under unfavourable conditions, to this sector of economy. Despite the fact that private companies represented over 98 percent in the structure of the economy of the Republic of Srpska, they realise its credit arrangements under rather unfavourable conditions in comparison to the public and state enterprises. This is indicated by the reduced rate of lending by deposit banks in the last two years. The reasons for such business policy of deposit banks, in part, is a result of the ownership structure of the share capital where state capital accounts for only $6 \%$, while the share of foreign private capital is over $73 \%$.

Many participation of private and foreign capital had, of course, an influence on the interest rate by which loans are sold to the real sector of the economy. The second part of the weakening of lending to the real sector, banks justify with the high risk of the investment, due to general illiquidity caused by the global financial crisis, and with a number of other internal factors. The research results show that the deposit banks do not play, even nearly, a role in the development of the real sector in Republic of Srpska.

\section{References}

Banking Agency of the Republic of Srpska, Annual reports for 2011, 2012, 2013, 2014, 2015, Banja Luka

Lorens J.G., 1976., Principles of Managerial Finance, Harper and Row, Publishers, Inc., New York

Plakalović N., 2004, Monetary Economics, Institute for textbooks and teaching aids, Srpsko Sarajevo 
Rose, P., Hudgins, S., 2005, Bank Management and Financial Services, Data status, Belgrade

Starčević V., Subotić S., 2012, Potential possibilities of financial institutions in financing the business sector of B\&H with the aim of overcoming the economic and financial crisis, The Faculty of Economics in Subotica No. 27, Faculty of Economics, Subotica

Šoškić D., Živković B., 2006, Financial Markets and Institutions, Faculty of Economics, Belgrade

Vunjak N., Kovačević Lj., 2006, Banking (Bank Management), Proleter, Bečej, Faculty of Economics, Subotica

Retrieved from https://www.abrs.ba/, accessed on 4.8.2017

Retrieved from www.europa.eu.int/coom/, accessed on 3.8.2017

Retrieved from www.irbrs.net, accessed on 3.8.2017

Retrieved from http://www.vladars.net/sr-SP-Cyrl/Vlada/ Ministarstva/mf/Pages/ default.aspx, accessed on 3.22.2017

Retrieved from https://ec.europa.eu/commission/index_sl, accessed on 3.22.2017

\section{ULOGA DEPOZITNIH FINANSIJSKIH INSTITUCIJA U RAZVOJU REALNOG SEKTORA REPUBLIKE SRPSKE}

Apstrakt: Depozitne finansijske institucije su poznate po širokom spektru pružanja tradicionalnih finansijskih usluga, od tekućih računa i sistema planiranja štednje, do odobravanja zajmova preduzećima, klijentima i državama. U današnje vrijeme, depozitne finansijske institucije ne ograničavaju svoje usluge samo na one tradicionalne, nego ubrzano počinju sa pružanjem opštih finansijskih usluga, kao što su: trgovina hartijama od vrijednosti, zaštita osiguranja, planiranje finansija, upravljanje penzionim sistemima, pružanje savjetodavnih usluga kompanijama koje su u procesu fuzionisanja, kao i drugih novih usluga. U radu ce se identifikovati depozitne finansijske institucije koje posluju na području Republike Srpske i determinisati njihova uloga u razvoju realnog sektora. Istraživanja u radu treba da pokažu da li su depozitne finansijske institucije, kao izvori finansiranja, pokretači razvoja realnog sektora Republike Srpske ili su ograničavajući faktor razvoja ovog sektora.

Ključne reči: depozitne finansijske institucije, finansijske usluge, krediti, realni sektor.

\section{Authors' biographies}

Vitomir Starčević is Associate Professor of Monetary Economics at University of East Sarajevo, at the Faculty of Business Economics in Bijeljina. $\mathrm{He}$ is an author and co-author of numerous scientific papers in the field of monetary economics and business finance. His research papers have been published in the local and foreign journal and presented at various conferences. 
Slobodan Subotić is Assistant Professor of Business Finance at University of East Sarajevo, at the Faculty of Transportation and Traffic Engineering. He is an author and co-author of more than forty papers in the field of business finance and banking. His research papers have been published in the local and foreign journal and presented at various conferences.

Irena Đalić is Teaching Assistant of Marketing and Management at University of East Sarajevo, currently engaged in the Faculty of Transportation and Traffic Engineering. Her research interests are focused on entrepreneurship, transitional economy and small business. She is author of few research papers in the field of entrepreneurship and small businesses and marketing. Her research papers have been published in the local journal and presented at various conferences. 